A $10.9 / 3: 59$

HAWAII AGRICULTURAL EXPERIMENT STATION HONOLULU, HAWAII

Under the supervision of the UNITED STATES DEPARTMENT OF AGRICULTURE

BULLETIN No. 59

\title{
THE MACADAMIA NUT IN HAWAII
}

BY

W. T. POPE, Horticulturist

Issued November, 1929

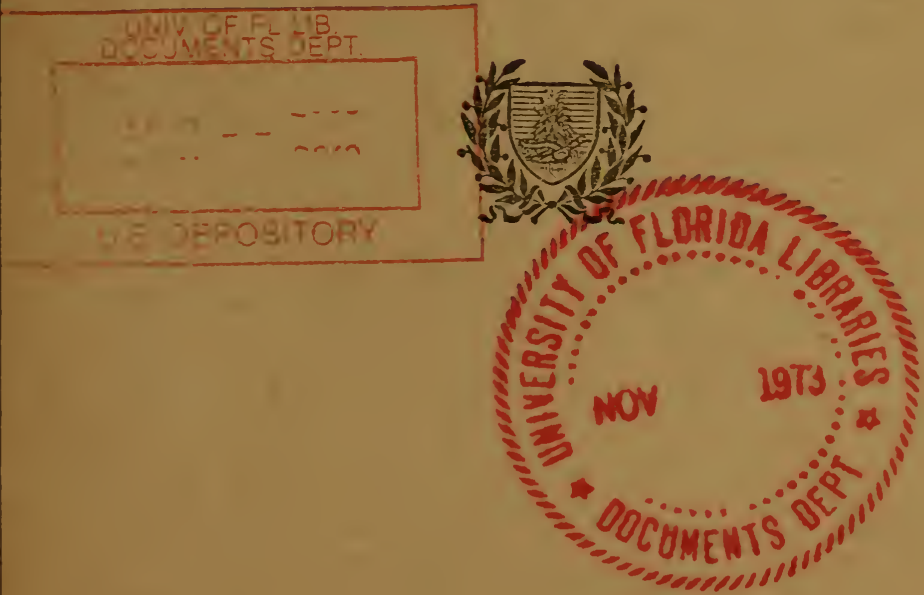

For sale by the Superintendent of Documents, Washington, D. C.

Price 10 cents 


\section{HAWAII AGRICULTURAL EXPERIMENT STATION, HONOLULU}

[Ünder the supervision of the Office of Experiment Stations, United States Department of Agriculture]

E. W. Allen, Chief, Office of Experiment Stations.

WALTER H. Evans, Chief, Division of Insular Stations, Office of Experiment Stations.

\section{STATION STAFF}

J. M. Westgate, Direcior.

W. T. Pops, Horticulturist.

H. I. Chung, Agronomist.

J. C. RIPPERTON, Chemist.

F. F. WILLEX, Superintendent, Haleakala Demonstration Farm, Makawao, Maui, Tcrritory of Hawaii.

H. K. LUM, Junior Tropical Agronomist.

JoH CAstro, Plant Propagator.

Chas. RioHTER, Assistant Chemist. 


\section{HAWAII AGRICULTURAL EXPERIMENT STATION HONOLULU, HAWAII \\ Under the supervision of the UNITED STATES DEPARTMFNT OF AGRICULTURE}

BULLETIN No. 59

\section{THE MACADAMIA NUT IN HAWAII}

By W. T. POPE, Horticulturist

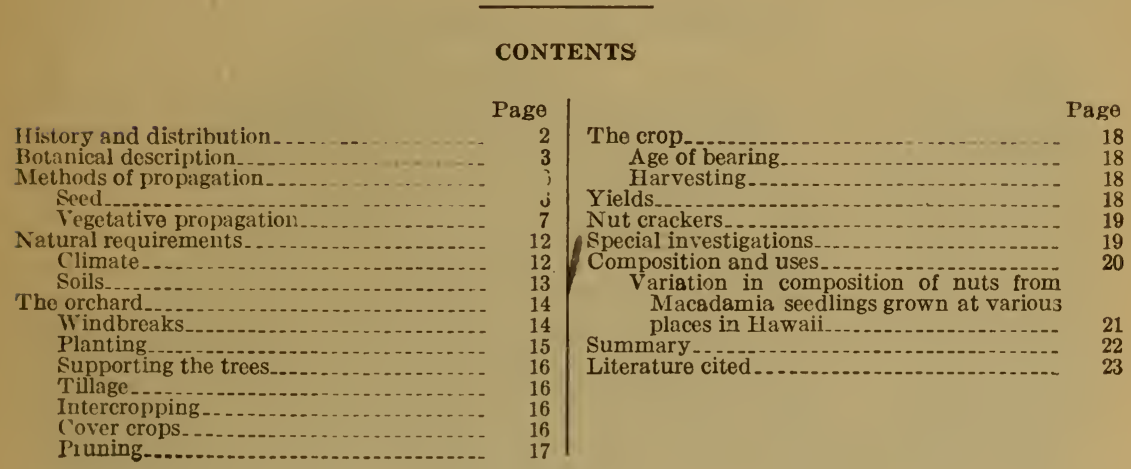

Macadamia-nut culture is rapidly assuming the proportions of an industry in Hawaii. Inquiries regarding every phase of the subject are being received by the station in increasing numbers. This is due largely to the interest created by the good yield of nuts from trees which have come into bearing in recent years. There is a growing demand for the nuts for food and for propagation purposes. 'The tree is aclapted to a wide range of moisture conditions but can not withstand low temperatures. There are certain areas in Hawaii where it probably could be grown with considerable success.

Macadamia-nut culture has received a stimulus in the passage of an act (No. 37) of the Territorial Legislature exempting from taxation all properties in the Hawaiian Islands which are used solely for the culture or production of Macadamia nuts. The act covers a period of five years, and became effective January 1, 1927.

Although it is rather generally thought that the Macadamia is of easy culture, numerous obstacles must be overcome and intricate problems must be solved before the tree can be grown to such an extent that its culture may be considered an established industry in Hawaii. Insect enemies, tree rats, and certain diseases some of which have already appeared, must be controlled; the fact that the tree is easily injured by wind must be taken into consideration; and,

$$
71615^{\circ}-29-1
$$


finally, a thin-shelled variety of Macadamia nut must be developed, for, although very satisfactory nut crackers are to be found on the market, a method of adapting them to the nut industry in Hawaii has not yet been fully worked out. The station has been endeavoring for a number of years to solve the more pressing problems and has briefly recorded the results of the experiments in progress in its recent annual report $(10, p .18,19 ; 11, p .8 ; 14, p .8 ; 20, p$. 22 $) .{ }^{1}$

The literature dealing with the Macadamia nut is very limited. It consists mostly of general information published in the form of magazine and newspaper articles. Several brief but valuable articles on the Macadamia nut have been published in Australia (16; $17 ; 19 ; 21, p .91)$. It is believed that a bulletin dealing with the subject in a general way will be of value to all Macadamia-nut growers at this time.

\section{HISTORY AND DISTRIBUTION}

The Macadamia-nut tree is indigenous to Queensland and New South Wales, Australia. Together with several related species it grows wild there. Certain variations or strains of Macadamia ternifolia are particularly valuable for their hard wood and edible nuts. The tree was probably first described in $1870(1, p .1181)$. A brief but excellent description of the Macadamia, including cultural requirements, was published in 1893 in Australia $(19, p .3-5)$. Since 1900 attention has been given to its cultivation as a nut-producing tree, and its culture has spread to other parts of Australia (16, 21), and to Hawaii $(2, p .698,4,9,15)$, California, Texas, Florida, and a number of Mediterranean countries.

Macadamia ternifolia is recorded as having been introduced into Hawaii for the first time by the late E. W. and R. A. Jordan about $1892(8, p .18)$, the latter of whom secured the seeds in Queensland and the former of whom germinated them and grew the trees at his home in Wyllie Street, Honolulu, where six of the original trees are still to be found. (Fig. 1.)

When the slopes of Mount Tantalus, back of Honolulu, were being reforested in 1892,1893 , and $1894(\%, p .21)$ under the supervision of the Board of Agriculture and Forestry of the Hawaiian Government, a small planting of about half a dozen trees was set at an elevation of 1,000 feet along with some wattle and Eucalyptus trees. The Macadamia trees did not fruit until about 1908 , probably because of their crowded condition. Three of these trees are on the land of Kewalo-uka, which had been set aside as an agricultural experiment station site by the Hawaiian Government and was made available for the use of the station in 1901. Three other trees of the same planting are to be found growing just across the line on the Territorial forest reserve. The boundary between these two tracts was not accurately determined at the time of planting. The trees began by 1910 to produce sufficient nuts to attract attention.

An earlier introduction of the Macadamia is reported by Forbes $(6, p .248)$ to have been made by W. H. Purvis, of Kukuihale, Hamakua district, Hawaii, about 1881. From Mr. Forbes' description of the tree, however, and particularly from his statement as to the

${ }^{1}$ Reference is made by italic numbers in parentheses to "Literature cited," p. 23. 
small and undesirable quality of the nuts, the trees are believed to have been of the well-known Gympie nut (Macadamia minor), of the Gympie district of Australia. This opinion is further corroborated by the fact that several Macadamia trees which produced small, undesirable nuts grew for some years in Kona, having been brought there as seedlings from the Hamakua district of Hawaii. These trees were recently cut down to prevent the spread of this undesirable variety, which corresponded very closely with the description of the Gympie nut given by Rumsey $(16, p .12)$.

Other introductions of the Macadania have been made by different persons in Hawaii direct from Australia, and through the United States Department of Agriculture, at Washington, D. C.

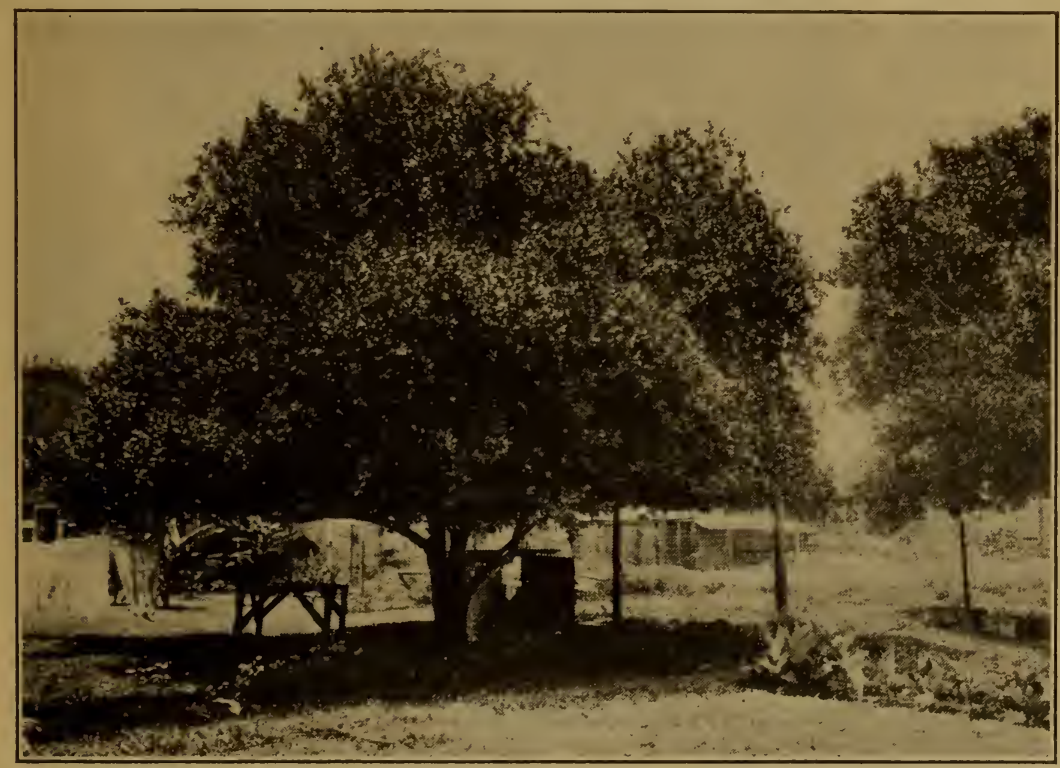

FIGURE 1.-Well-formed Macadamia tree about 36 years old, growing on the premises of the late E. W. Jordan, Honolulu

\section{BOTANICAL DESCRIPTION}

Macadamia ternifolia usually attains a height of about 30 feet, and the upright forms sometimes reach to a height of 50 or 60 feet; the foliage is dense and dark green; the trunk is 1 foot or more in diameter; the bark is of medium thickness and light gray in color; the wood is uniformly light gray, mottled, and often shows a pinkish cast; and the grain is coarse, tough, and fairly hard. The leaves are oblong-lanceolate, ranging from 3 or 4 inches to a foot in length, are sessile or nearly so, glabrous and shiny, and in whorls of three or four; the blade margins are serrated and somewhat prickly. The flowers are numerous, small, arranged in long spikelike racemes which are as long as the leaves or longer, and creamy white or pink; the perianth is minutely pubescent or glabrous, the reflex points are four in number and spreading, exposing four anthers each having a 
short stalk attached to the perianth throat; the perianth is split on the side to release the club-shaped style and stigma, and the ovary is covered with fine hairs. (Fig. 2.) The fruit consists of a 2 -valved leathery exocarp, and the endocarp, which varies in thickness from three-thirty-seconids to three-sixteenths inch, is very hard, and the surface is undulating to bumpy. The fruit is 1-seeded, usually globular, or occasionally 2 -seeded, in which case each nut is hemispherical. On maturity the exocarp splits, dropping the nut which is 1 to $11 / 4$ inches in diameter. If the nut falls in a damp place, the shell will absorb moisture rapidly and crack, and if other conditions are right the seed will germinate. (Fig. 3.)

Macadamia ternifolia var. integrifolia differs from M. ternifolia in that it is a smaller tree, and has a more spreading top. The leaves are usually smaller, each has a petiole about an inch long and a rather spatulate blade, and the margins are entire or with very few

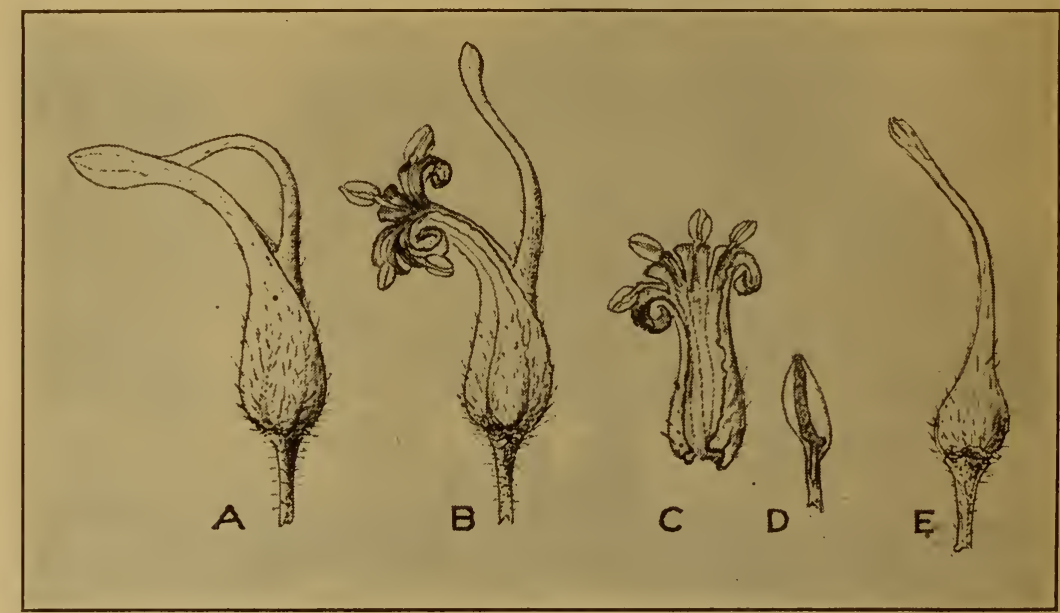

Figure 2.-Macadamia flower: A, Opening perianth; B, pistil and anthers released;

$\mathrm{C}$, interior view of perianth; $\mathrm{D}$, expanding anthers; and $\mathrm{E}$, developing ovary

spines. The flowers are creamy white and are borne in clusters. Usually only 2,3 , or 4 flowers of each cluster set fruit. The nuts are more nearly spherical, the surface of the shell is smoother, and in size they average a little smaller than do those of $M$. ternifolia.

The Macadamia tree has various common names. In a large part of Australia it is well known as the Queensland nut, and in other parts it is called the Australian nut. It is known by still other names in different localities in Australia. In Hawaii it is most generally called the Macadamia. Walter Hill, the first director of the Brisbane Botanical Gardens, is credited with having discovered the nut while studying the flora of the Moreton Bay district. It was botanically named Macadamia ternifolia in honor of Dr. John Macadam, president of the Philosophical Society, Victoria, Australia. The specific name ternifolia has reference to the arrangement of the leaves in whorls of three at each node. The genus Macadamia belongs to the natural order Proteaceae, as do also the well-known groups of trees Waratah, Grevillea, and Hakea. Other species of the genus are 


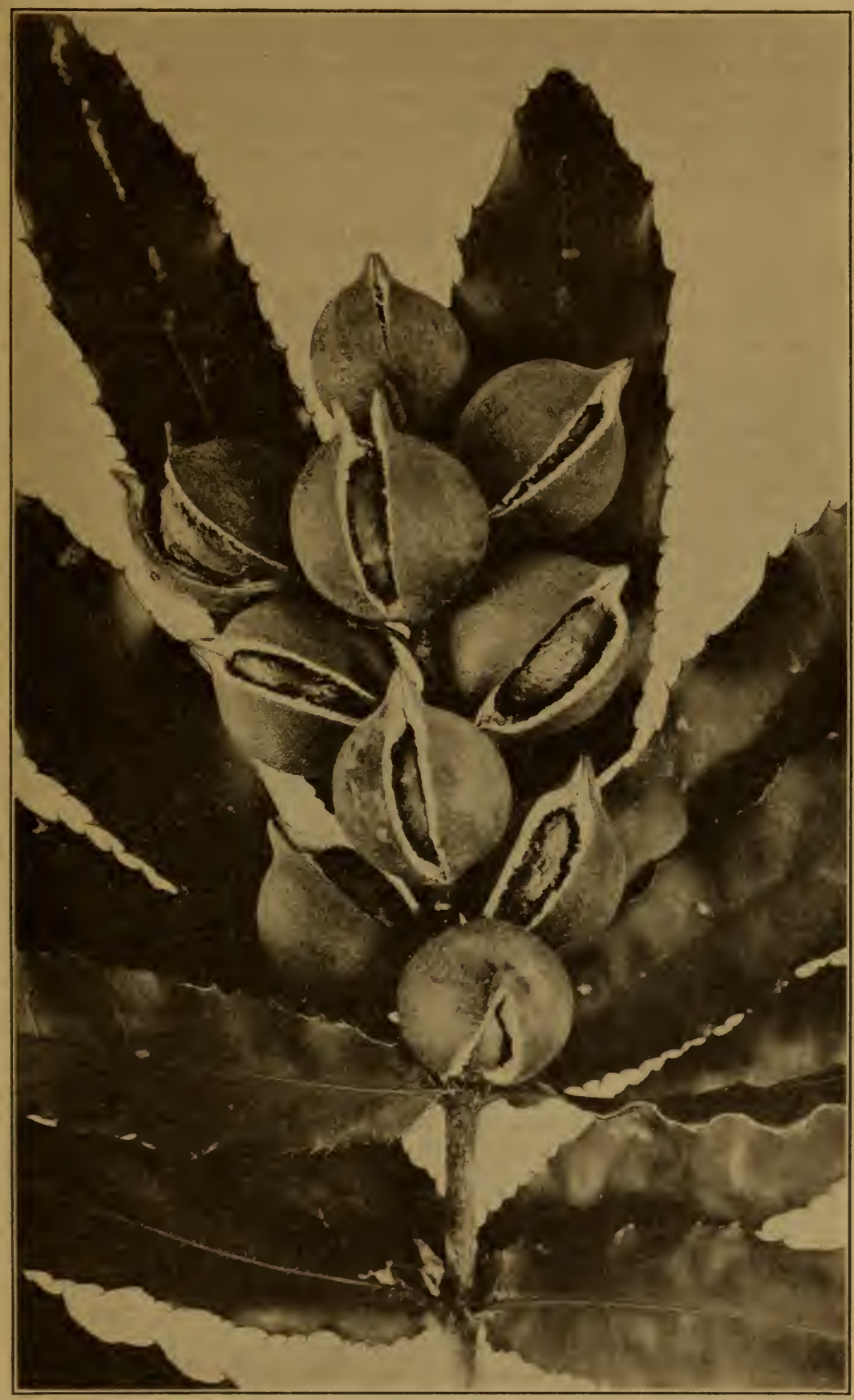

Figtae 3.-Macadamia ternifolia. The nuts are borne in clusters on each rachis; splitting of the busk indicates maturity 
M. whelanii, of Queensland, a medium-sized tree; M. prealta, another Queensland tree, sometimes lofty, which has a reddish wood that is used for cabinetmaking, as are also the woods of nearly all the other species; $M$. lowii, or the Maroochie nut of Queensland, the tree of which grows 15 to 20 feet high, forms 6 to 20 woody stems from a hard, spreading rhizome, and bears pointed, ribbed, edible fruit about $1 \mathrm{inch}$ in diameter. The nuts of the three last-named species are said to have little food value.

\section{METHODS OF PROPAGATION}

Heretofore the Macadamia tree has been propagated entirely by seed. Occasional trees of unusually fine habits have been produced, and attempts have been made to establish and standardize varieties of them. Planting selected seed and giving the resulting seedling good culture can not be relied upon to accomplish this. The extent of the natural variation of seedling fruit and nut trees is well known, and the Macadamia has proved to be no exception to the rule. It is necessary to use vegetative methods of propagation, that is, root cuttings or grafts, if the grower would be assured that his trees will be prolific and the product of uniform good quality. For several years the station has been conducting experiments in vegetatively propagating the Macadamia and has successfully worked out a comparatively easy method of grafting that will eventually materially aid the Macadamia industry in Hawaii.

SEED

Propagating the Macadamia from seed is not difficult. Different methods of germinating the seed are employed. The seeds may be planted in the soil where the trees are to remain, but when this method is practiced the seedlings show variation in vigor and there is difficulty in selecting the most promising kinds. Some growers germinate the seeds in nursery rows and when the seedlings are of the proper size select, dig, and transplant them into their permanent places in the orchard. Because of the unsatisfactory soil conditions at the station and for the sake of convenience in delivering the seedlings to cooperative experimenters, the station has practiced the method of germinating the seeds in propagating beds of ordinary coral (beach) sand. The sand is first washed free from salt and then placed in a large propagating bench a foot deep, in the open sunlight. The selected nuts are planted while they are fresh, immediately following maturity, 3 to 4 inches below the soil surface, and are kept moist. They require from 20 to 30 days to germinate and produce active leaves. In another period varying from 30 to 60 rlays the resulting seedlings may be transplanted to gallon tin containers, or to 8-inch pots filled with mediumly rich, preferably sterilized, soil. They may be kept growing thus for a year from the date of planting the seed without becoming seriously pot-bound. The roots usually develop sufficiently in three to five nonths to permit transplanting the seedlings to the orchard. Seedlings which are grown to supply rootstock material for grafting experiments may be utilized at any time that their size and the nature of their wood is suitable for making the unions. 
The lower part of the stems of the seedling is often crooked. It has been frequently suggested that this defect can be remedied by planting the seed with the small holelike depression face down. This depression in the nut is found directly opposite to the embryo. At the station an experiment with 50 nuts failed to indicate that position of nuts at planting time influenced the nature of the stem cleveloping from the caulicle. In some instances the seed was turned completely over by the growing seedling. In other instances the stem grew straight although the seed had been planted with embyro down. (Fig. 4.) The station observations indicate that crookedstem development is due to the fact that moisture conditions were unsuitable at the time the seed was germinating.

\section{VEGETATIVE PROPAGATION}

Experiments in connection with the regetative propagation of the Macadamia at the station were begun in 1922. Attempts to graft seedling trees were made without success at that time, although both seedlings growing in the field and in gallon tin containers were used. Another unsuccessful attempt was made with young trees during 1923. A much more extensive experiment was begun by Ralph Moltzau, a student employee of the station, in 1927. He tried branch and root cuttings of different forms in different mediums, air layering, inarching, budding, and various other kinds of graftage. The successes obtained thus far have been with cuttings, air layers, inarches, and grafts.

From a large number of seedlings which were germinated in the fall of 1926,150 were selected as rootstocks for the vegetative propagation work. The variation in size of seedling seemed to be an unimportant factor since successes were obtained with stocks which ranged from three-eighths to three-fourths inch in diameter. The larger sizes were used mainly in inarching where the scion branches were correspondingly large. Trees of different sizes and ages in the station orchard and in the orchards of cooperative experimenters furnished such other material as was needed.

Results of experiments at the station show that the Macadamia may be successfully rooted as cuttings. Factors combining to make the process possible are (1) a deep and thoroughly underdrained soil in which had become incorporated much organic matter from decomposed leaves and other forest litter; (2) a temperature that ranges between $65^{\circ} \mathrm{F}$. at night and $70^{\circ}$ in the daytime; (3) protection from the intense heat of the sun at midday by some method of shading; and (4) an abundance of moisture. The most successful cuttings were made from rather mature branches 1 to 2 feet long and one-half inch or more in diameter. Such cuttings develop a good root system in three to five months. The new top growth bursts forth as tender branches, grows rapidly for a few days, and then slows down, and the branches harden preparatory to making another period of active growth. The rooted cuttings should be transplanted at a time when growth appears to be the most dormant.

Standardizing varieties of Macadamia as nursery stock by means of cuttings may prove to be the most practicable method of largescale propagation. However, this method may not be practicable under certain circumstances, as for example when certain desirable 
varieties indicate the necessity for a more resistant root system. In the Hawaiian Islands such root troubles may be brought about by either pathological or soil conditions, but as yet these factors have not been a cause of concern in the culture of the Macadamia. In

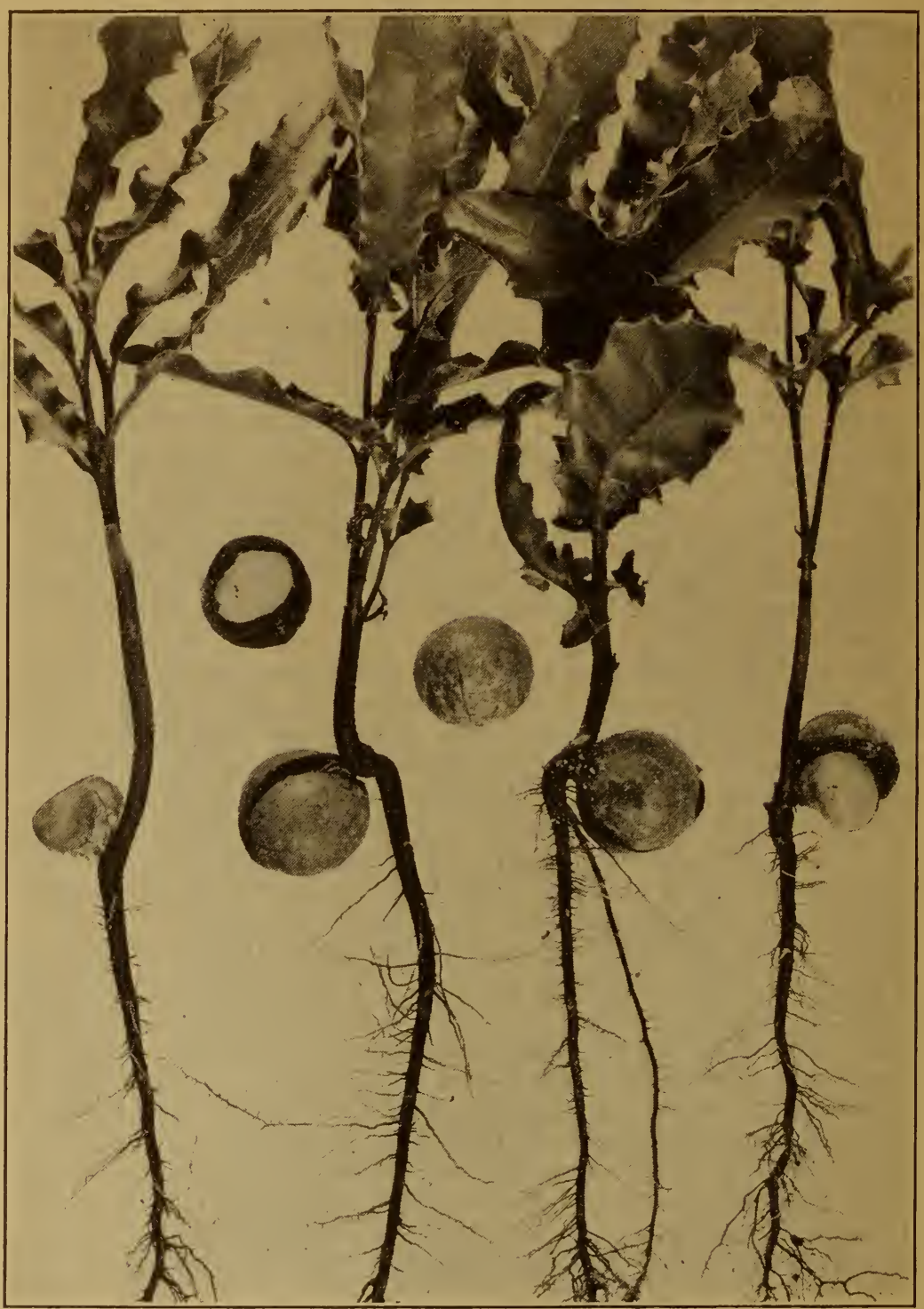

Figure 4.-Germinated Macadamia nuts indicating that position of seed is not necessarily the cause of crooked seedlings

semitropical countries where the culture of the Macadamia is to some extent being tried, the matter of resistance of the tree to cold, and particularly of the root system to low soil temperature, may also be a subject for investigation of the use of more resistant rootstocks. 
Other related and possibly more resistant species not now utilized may then be brought into use as rootstocks.

A number of air layerings were successfully made at the station. Branches about 1 inch in diameter and 4 feet in length were girdled, the bark being removed to the sapwood. The wound was then surrounded with a sterilized mass consisting of equal parts of sphagnum moss and rich potting soil held firmly in place with burlap and string. For further security the mass was surrounded with a tin can cut and spread to fit snugly and bound in place with wire. Wellrooted branches were ready to be cut off and potted as new trees in 30 to 60 days. Air layering of the Macadamia may be accomplished in the same way as is done with the litchi, and with about the same degree of success $(13, p .7)$. (Fig. 5.)

Inarching was found to be difficult, especially where a high scaffolding had to be used to bring the rootstocks to the desired scion branches of large trees. Root sprouts and basal sprouts of orchard trees were more easily inarched. Unions 6 to 15 inches long proved to be the most satisfactory. In making these unions the bark and wood one-half inch wide were cut away from the side of both stock and scion at the point of union, and the two exposed surfaces were bound tightly together with raffia. The entire union was then sealed with a coat of lukewarm liquid paraffin. These inarches were separated from the parent tree after 28 to 30 days. The top of the seedling, leginning just above the union, and the part of the scion just below the union were cut off, and the exposed surfaces of the newly formed tree were covered with a protective coat of grafting wax. ${ }^{2}$ The foliage surface was then reduced by clipping off about half the number of leaves. Nineteen days after separating the new tree from the old one, a number of buds began to lengthen into preliminary branches for forming the top.

In the grafting experiments sereral kinds of unions were tried, 1-year-old seedling stock being used for the purpose. The diameter of stem of these seedlings at the point of union raried from threeeighths to five-eighths inch. The kind of grafts tried were shield budding, whip graft, wedge graft, and side-tongue graft. None of the first three kinds of grafts grew, but a number of the sidetongue unions were successful. In making the side-tongue grafts the scion of both the desirable variety and the seedling stock were of about the same diameter and vigor of growth. The material varied from five-sixteenths to one-half inch in diameter. (Fig. 6.) The seedlings were grown in sterilized soil in tin containers or earthern pots and varied in age from 8 to 15 months. The wood was fairly hard, and it was necessary to use a strong, thin-bladed grafting

2 The following recipe for a special grafting wax for use in the Troples has been used at the station for several years with excellent results: To 1 part tallow by weight add 8 parts beeswax and 4 parts resin. Melt the tallow in a suitable iron kettle over a slow fire; then add the beeswax. As soon as the nixture begins to boil add the resin gradually. stirring continuously until it melts. Continue the boiling for five minutes, then remove the kettle from the stove and rour the liquid through clieesecloth into a large container of cold water. When the mixture has thoroughly cooled, work it with the hands until it becomes tough and doughy. Thorough cooling is very important to prevent lump formation. Kneading may be difficult at first, but becomes comparatively easy after a $f \cdot w$ moments. To prevent the wax from adhering to the hands, grease them slightly with tallow. As soon as the wax assumes a creaniy, silken color it may be worked into rolls alout 2 inches in diameter and 5 inches in lellgth, then wrapped in waxed paper. The wax is then ready for immediate use, or it may be stored for future use. If It hardens, kuead in a very small amount of tallow. 
knife. Each graft was made with thoroughly cleansed knife and hands to prevent infection by bacteria, dirt, and the like. Even the oil remaining on the blade after whetting was removed with alcohol,

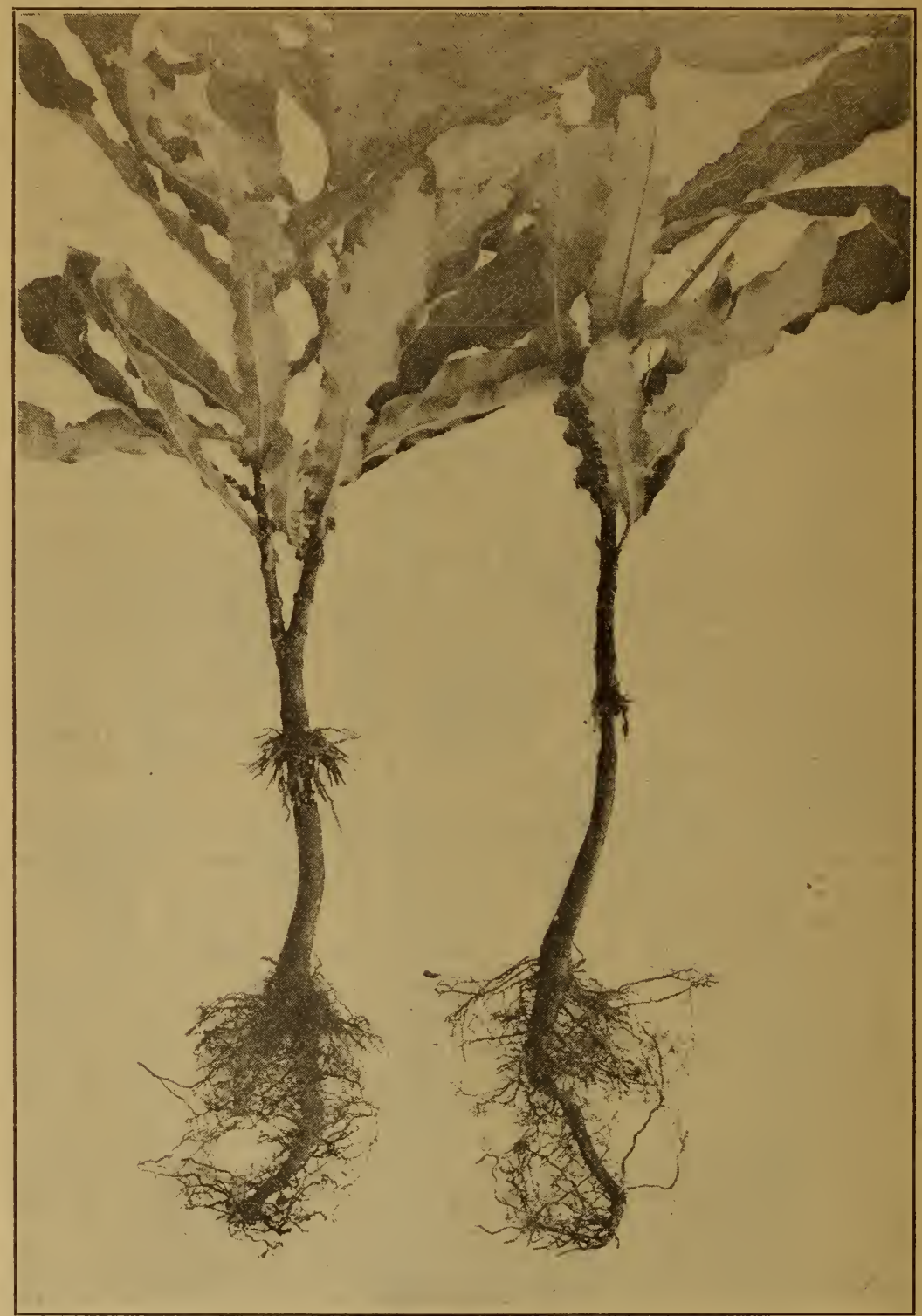

Frgure 5.- Seedling Macadamia trees which have been caused to root by the airlayering method of rooting plants

and the knife was dried with a clean piece of cheesecloth. From the beginning of the cut to the completion of the union the work was done without delay. The cut surface was made about $2 \frac{1}{2}$ inches long, it was smoothed off, and the edges were not bruised. A tongue 
about an inch in length was added to aid in giving more cambium surface where growth united the stock and the scion and to hold the union firmly where it was bound with raffia. This is of vital importance to the success of a graft. 'The whole outer surface of the

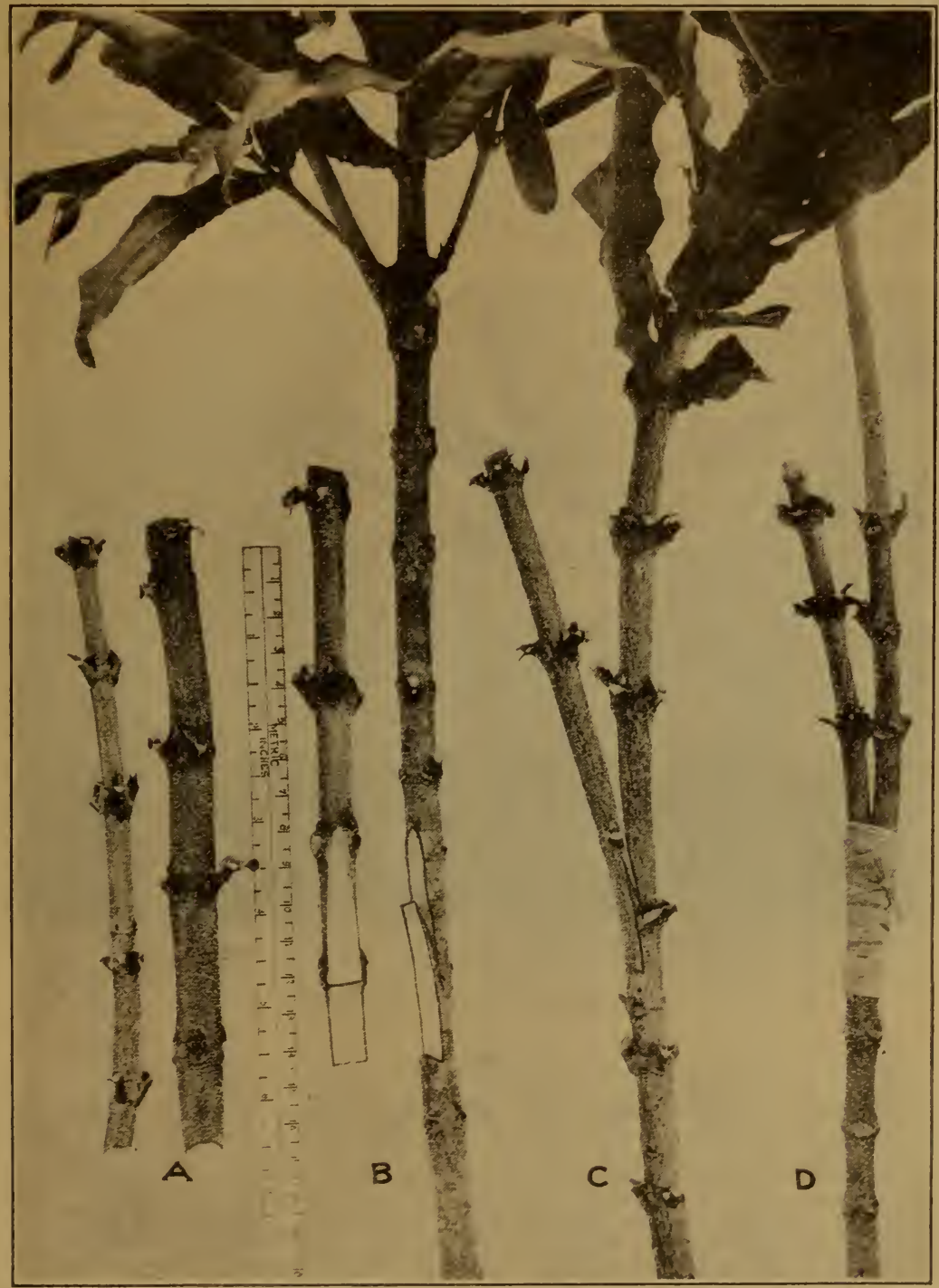

Figure 6.-Side-tongue method of grafting the Macadamia : A, Variation of scions: $B$, cuts made in scion and stock; $C$, scion in place; $D$, union tied firmly and ready to receive a coating of liquid parafin

union, including the tying material, was also protected from outside contamination by a coating of lukewarm liquid paraffin applied with a brush.

Paraffin fills every crack and rapidly hardens into a clean, waterproof, air-tight coat which not only protects the graft, but also 
permits a continuance of such vital processes as are necessary for the success of the union. The grafted plants were kept in a moist slathouse to afford them protection from the wind and partial shading from the strong sunlight. The scions of these grafts made no visible growth for 14 to 28 days. They then grew rapidly. (Fig. 7.) After about 40 days the seedling tops were severed at the point of union, and the cut surfaces were coated with grafting wax. In a few clays the grafted trees were transplanted to 12 -inch pots to make further growth preparatory to their removal from the slathouse to the open sunlight. After they have been allowed to remain for sereral weeks in the open to establish a good root system and wellhardened branches and foliage, the grafted Macadamia trees may be transplanted to their permanent place in the orchard.

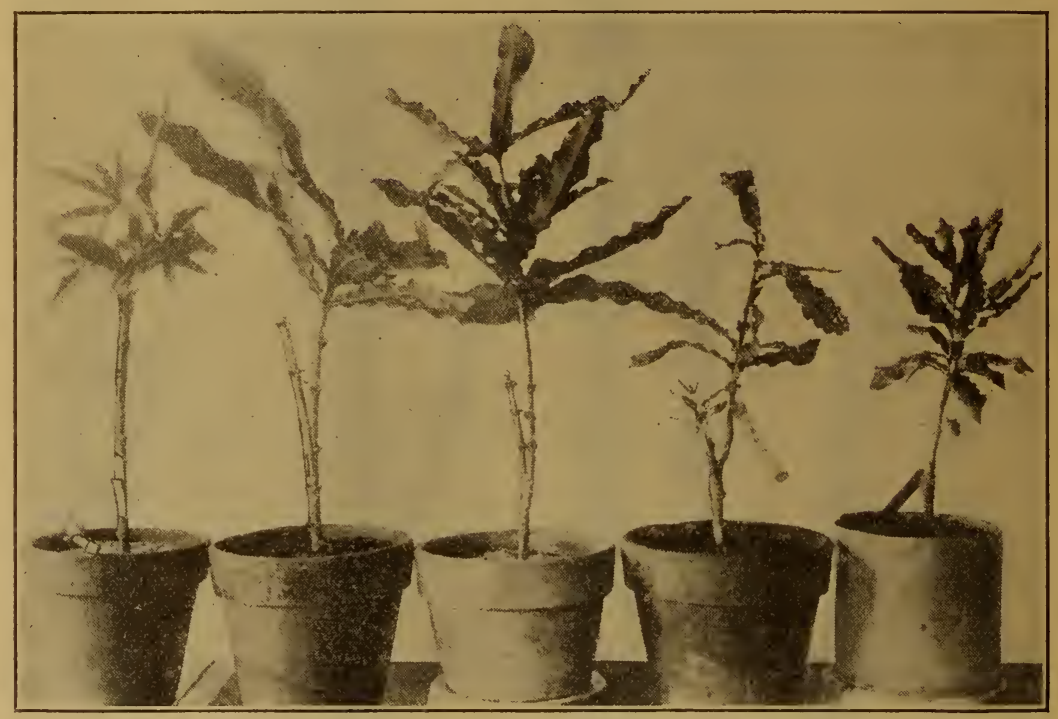

Figure 7.-Various stages in grafting young Macadamia trees

\section{NATTURAL REQUIREMENTS}

\section{Climate}

In climatic requirements the Macadamia tree may be considered to be strictly tropical. Turner $(19, p .4)$, botanist for New South Wales, states that the tree is suited to localities where frost does not occur. For some years the cultivation of the Macadamia has been attempted in parts of France, Florida, and California, but the writer has been unable to learn whether the nuts were grown on a commercial scale in these places. In Hawaii, the Macadamia may be found growing from sea level to an elevation of 2,200 feet, and possibly at still higher elevations. On Oahu the trees have done well in localities where the annual rainfall is 35 to 50 inches. Several Australian publications call attention to the fact that the Macadamia has drought-resistant properties which possibly indicate its adaptability to semiarid regions. However, experiments and observations in 
Hawaii indicate that a full crop may be expected only after the tree has received considerable moisture. Irrigating liberally in basins at least once a month during the drier part of the year has been found to be a good practice at the Hoaeae ranch, Waipahu, Oahu, where the Robinson brothers have an excellent young Macadamia orchard of bearing age. (Fig. 8.)

\section{SOILS}

Results of investigation indicate that the Macadamia tree is adapted to many kinds of soils. Only in extreme cases, as for example where the soil is practically a loose sand, or very rocky, or an exceedingly stiff clay, does the tree fail to grow. Like most other

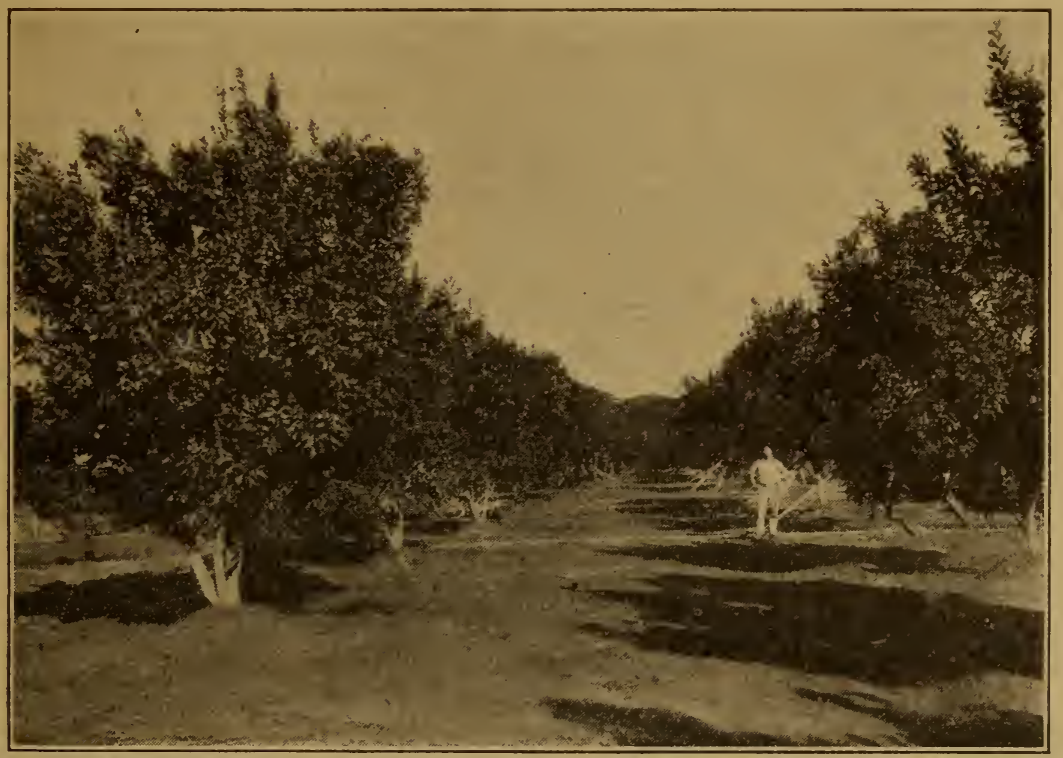

Figure 8.-Macadamia orchard at Hoaeae ranch, Waipahu, Oahu, which is kept cultivated and irrigated by the basin method. The trees are set in rows 30 feet apart each way

trees, however, it thrives best in a rich, deep, and thoroughly underdrained soil. Turner $(19, p .4)$ observed that some of the trees in Australia were fine specimens and produced nuts in abundance although growing in a very light sandy soil which was fairly rich in humus. Those who have studied the Macadamia are of the opinion that preparatory to the planting of the trees in orchard form the soil should be deeply plowed and otherwise cultivated as is recommended for other fruit and nut trees. The term deeply plowed has a variable meaning in different orchards, particularly those in different localities in Hawaii. In some places the land can not be plowed to a depth of more than 8 to 10 inches, whereas in others the land may be plowed and subsoiled to a depth of 18 to 24 inches and even deeper. On certain sugarcane, pineapple, and banana plantations in parts of Hawaii, plowing to a depth of 2 feet has been found to be very advantageous. Where only shallow plowing can be done 
the soil is unsuited for orchard work and should not be planted with crop-producing trees. The rolcanic soils of Hawaii vary greatly in their mechanical nature. Some of these are sufficiently loose and underdrained to permit of their use for orchard planting without plowing. The black sand and a-a soils are excellent examples of these. The black sand or cinderlike deposits are sometimes of considerable depth and have a thoroughly decomposed surface varying according to the amount of moisture received and the humus developed. The a-a soils are very similar, but may be said to differ in early formation, as they originally consisted of very rough lava flows, the surface of which has been decomposed by the natural elements. The rather open structure below the surface of these soils affords an unusually favorable underdrainage. Most trees thrive in such soils provided they are given an abundance of moisture. The excess water in sinking away draws in the air, thus aerating the soil and carrying an optimum supply of oxygen to the roots.

The Macadamia in its native condition usually is found growing in the rich alluvial soils bordering rivers and creeks in the coastal districts of the southern part of Queensland and in the northeastern part of New South Wales, Australia.

\section{THE ORCHARD}

\section{WINDBREAKS}

In the Hawaiian Islands the Macadamia orchard should be sheltered from the prevailing winds. Gentle trade winds are desirable, but at times they may prove to be too severe for the young trees. Temporary protection from wind should always be given to the voung trees regardless of whether permanent protection is necessary. Temporary protection may be supplied in the form of burlap tacked to three stakes on the windward side of the trees. On several occasions in the Hawaiian Islands young Macadamia trees varying from 2 to 5 years in age have blown over, not as the result of their being uprooted, but as the result of their breaking off in the ground immediately above the spread of the root system. The outer or sapwood and bark break under the hard, twisting pressure of the tree continued for several hours in a strong wind; and although the tough heartwood may still remain unbroken, the tree eventually bends over and dies. Death is certain to occur when the tree is thus injured, even when it is propped in place immediately after being injured, because the growing tissue surrounding the base of the trunk has been ruptured beyond recovery.

Large, permanent windbreaks when necessary should be grown on the windward side of the orchard. Such rapidly growing trees as Eucalyptus (E. robusta), mangoes (Mangifera indica), and ironwood (Casuarina equisetifolia) might be used for the purpose. These may be set alternately in three rows 10 feet apart and the same distance apart in the row. The row nearest to the prevailing wind should consist of Eucalyptus trees which make tall, strong growth; the central row should be made up of two kinds of trees, Eucalyptus and grafted mango trees arranged alternately in the row. 'The mango has a dense and resistant top and if grafted of good variety has the additional value of producing good fruit in 
season. The row which is next to the Macadamia orchard should consist entirely of ironwood. The horizontal roots of these trees can be prevented from entering the soil occupied by the orchard by maintaining a narrow ditch 3 to 4 feet in depth at a distance of about 4 feet from the row of ironwood trees. Preventing the spread of roots on one side of the ironwood trees does not have any serious effect on them.

\section{PLANTING}

In setting an orchard of either seedling or grafted Macadamia trees, care should be taken to use only those of good form and rigor. In most parts of Hawaii pot-grown trees are preferred to nursery-grown trees. Sterilized soil of a desirable mixture should be used in developing the former. Such soil is practically free from nematodes, insect pests, plant diseases, and weed seeds. Very little control of these enemies is possible in the field. The container's of small trees may temporarily be kept on slats placed on the ground, or the pots may be set on plant benches. Potted seedlings can be given individual attention and protected against irregularity of growth and the attacks of the leaf roller (Amorbia emigratella), which sometimes is found on the newly developed leaves. In places where nut grass (Cyperus rotundus) can not be controlled in the field, it is likely to rob the young trees of plant food and greatly to interfere with their cultivation. Pot-grown trees are also easily grafted and may be given special attention during the transition from seedlings to standard trees. Trees of the Tropics do not have a period of dormancy as do deciduous trees of the Temperate Zone, and hence are more difficult than the latter to transfer from the nursery to the orchard. When the young Macadamia trees are dug up from the field nursery the soil tends to fall easily from their roots. Such trees, although carefully transplanted, may fail to survive. Pot-grown trees can be removed from the containers with little disturbance to the root system and transplanted without loss.

In the Hawaiian Islands the Macadamia tree may be set in the crchard during any month, but preferably it should be set in the fall or the winter, when the temperature is lower and moisture abundant. There are sereral ways of arranging orchard trees in rows. The most important of these are the square, triangle. hexagonal, and quincunx. These methods are described in popular horticultural books. The first is the more commonly used in orchard work and is quite satisfactory for the Macadamia. The trees are set in rows 30 by 30 feet each way on the square. (Fig. 8.) This will permit the growing of 48 trees to the acre. The trees do best when they are set while small, either during the latter part of their first year, or during the first half of the second year. The holes for planting should be at least 2 feet across and about as deep. Surface soil containing some coarse sand and enriched with well-decomposed barnyard manure should be placed in the bottom of the holes hefore the trees are set. A similar mixture should be pressed in firmly about the ball of earth on the roots so that the natural ground line of the tree will be 2 or 3 inches lower than the natural surface of the orchard to form a shallow basin about each tree to hold water 
in case irrigation is necessary.. The basin will fill with earth as the area is cultivated, establishing the tree a little lower in the ground, as is desirable in Hawaiian orchards. Each tree should be watered liberally immediately after it is planted.

\section{SUPPORTING THE TREES}

In windy localities the trees should be supported by means of firm stakes, one per tree, driven into the ground on the windward side of the orchard. Each tree should be securely tied to its stake with a strip of cloth. Individual trees often require some support additional to that given by windbreaks to protect them from winds occurring during the period of rapid growth in the third, fourth, and fifth years. A series of No. 12 galvanized guy wires may be used to brace the trees. Each wire is attached separately around the main branches and above a crotch where the tree top is formed at the crown of the trunk. One or two feet of old $3 / 4$-inch rubber hose should be placed over the wire to prevent the bark from being injured at the point of contact. These braces are securely fastened, each to a strong stake driven well into the ground, with the point at an angle toward the roots and at a distance of 4 or 5 feet from the tree. One brace should face the direction of the prevailing wind, and the others should be set equal distances apart in the remaining portion of a circle about the tree. A little extra work and expense of this kind often maintains a tree through several dangerous year's until the trunk has attained sufficient size and strength to be selfresistant to unusually strong winds.

\section{TILLAGE}

Thorough tillage is essential in any orchard in Hawaii. Cultivation opens up the soil, admitting more water and giving better aeration and underdrainage; hence, it makes more plant food available for the orchard trees. It also suppresses weed growth, which would utilize the moisture and plant food needed by the trees. A large amount of plant food and moisture is removed from the soil by weeds.

\section{INTERCROPPING}

Growing other marketable crops between the tree rows during the first few years is advisable in most orchards. However, such crops must not be planted so close to the trees as to interfere with their development. Where the conditions are right, two rows of papayas may be planted in the 30 -foot space between the Macadamia rows. If the papayas are set at the customary distance of 8 feet apart the 11 feet of space remaining on each side will be sufficient for the orchard for several years. Such other crops as tomatoes, sweetpotatoes, string beans, peppers, squash, peanuts, and alfalfa may also be grown between the young tree rows. At elevations of about 500 feet, the roselle, poha, chayote, and Passiflora sp. may profitably be grown.

\section{COVER CROPS}

Orchard cover crops should be grown during the rainy season. They prevent surface washing and retain much of the water of 
torrential rains until it has had ample time to soak into the earth beneath the trees. Another advantage of the cover crop is the green manure which it furnishes as humus when plowed under. Among the leguminous plants that may be used for this purpose are cowpeas (Vigna catjang), namea ( $V$. lutea), mungo bean (Phaseolus mungo), soybean (Glycine hispida), Crotalaria ( $C$. juncea), pigeon pea (Cajanus indica), and white sweetclover (Melilotus alba). Practically all these have been tried as orchard cover crops at the station with fairly good results. The cowpeas have given the most satisfaction.

\section{PRUNING}

From the beginning of the growth of the young Macadamia in the orchard the aim should be to develop a strong, symmetrical tree having a large trunk and a spreading top. The large branches forming the framework of the top should arise from clifferent points of the upper portion of the trunk and be so shaped and strengthened as to sustain heavy crops of fruit. Pruning is the most commonly practiced method of training the Macadamia into the desired form. (Fig. 1.)

During the early growth much of the formation of the tree may be controlled by hand pruning, that is by pinching out, with the thumb and finger, from time to time all buds which would become undesirable branches. By this method and with the aid of the pruning shears the framework of the future top may be developed and excess terminal growth retarded. Neglecting to prune the trees may result in their breaking down under the force of strong winds. Pruning after the trees have reached bearing age should be done shortly after the crop has been harvested. Pruning, moreover, should be done regularly because delay necessitates heavy pruning later, which is likely to force vegetative growth rather than fruit wood. Sharp pruning shears should be used for the removal of small branches, and the pruning saw for large limbs. All wounds which are three-eighths inch across or larger should be smoothed off with a sharp pruning knife and painted to prevent decay, or the entrance of insects. Asphaltum paint has been satisfactorily used but a rather thick mixture of house paint may also be used to advantage.

Another method of forming the Macadamia into a spreading top has been worked out by T. C. White, of Kealakekua, Island of Hawaii, and practiced by him and by Grant Bailey, manager of the Hoaeae ranch, Waipahu, Oahu. After the early branches of the trees have been allowed to grow naturally to the fourth, fifth, or sixtr year, the long, upright branches are tied down to a horizontal position with No. 14 galvanized wire. The place of contact is protected with cloth to prevent injury to the bark, and each end of the wire is tied to separate stakes some distance apart to prevent swaying of the branches in the wind as much as possible. Holding the branch in this position tends to check the terminal growth and to produce laterals which build up the spreading top. The wires may be removed a few years later when the limbs to which they are attached have grown firmly into the position desired. This method greatly strengthens the framework of the top. (Fig. 8.) 


\section{THE CROP}

AGE OF BDARING

The age of bearing and the seasons of flowering and fruiting naturally vary greatly with seedling Macadamia trees. These habits are also influenced somewhat by environmental conditions, such as the soil, the temperature, and the amount of moisture furnished the crop. Certain of the trees in one of the station cooperative experiments in the Kona district came into bearing at 5 years of age. Other Macadamia trees have been reported as producing a few nuts in their fourth year. It is generally believed, both in Hawaii and in Australia, that the first crop of consequence appears in the seventh year, with some tardy exceptions which may delay fruiting till the tenth or twelfth year, or even later. Observations indicate that many of these long delays are caused by some unsuitable environmental condition. The bearing age of the Macadamia is very similar to that of many other cultivated nut and fruit trees. However, the blossom and bearing seasons are somewhat different. Macadamia trees of bearing age usually blossom and mature nuts twice a year, the first crop appearing in April and May, and the second in October and November. The nuts require about six months from time of flowering to mature. Usually the largest crop develops from the spring blossoms and matures in the fall. Some trees have their fruiting period so lengthened in the year as to be considered everbearing.

\section{HARVESTING}

Harvesting the crop is far from difficult. On full maturity of the fruit the outer covering splits open (fig. 3), and the nuts drop to the ground. At this time they are considered to be too fresh for immediate use, but they can be eaten after a few weeks.

The gathered nuts should be stored in a dry place sheltered from the sun and the rain and given protection against the attacks of insects and rats. Marketing should begin in the course of a few weeks after gathering and should be completed within the next three months.

Macadamia nuts, like most other tropical nuts, do not retain their best flavor for a very long period unless they are preserved in salt and packed in air-tight containers.

\section{YIELDS}

Few definite records as to yields of the Macadamia are as yet available. However, results of investigations in Australia and in Hawaii indicate that yields vary greatly, and that the differences are due to both seedling variation and environment. As with most other nut and fruit crops, the Macadamia must receive good culture to make large yields. Rumsey $(16, p .11,15-16)$ refers to a small orchard at Rous Mill, Australia, in which the trees produced crops varying from 1 to 3 tons, but fails to give the number of trees producing or the area occupied by the crop. This orchard was about 40 years old in 1927 and was the only commercial one in that part of Australia until rather recently. The trees were reported as being 
only 12 feet apart and their branches as greatly interlocking except in a portion of the orchard where considerable pruning had been done in an experiment to give the interior of the trees air and light. As a result of the investigation, Mr. Rumsey felt convinced that Macadamia trees should be set 30 feet apart when they are planted in orchard form. Rumsey $(10, p$. 34), quoting N. C. Hewitt, of Tweed Heads, gives a probable return of $\$ 250$, equivalent to $\$ 1,216.65$, per acre, starting from a conservative estimate of $£ 25$, equivalent to $\$ 121.65$, per acre in the fourth year (seventh year in the south), and increasing to the fiftieth year. This would amount to about 5,000 pounds of nuts per acre, or an average of about 100 pounds per tree from trees presumably set at the rate of 50 to the acre. A well-informed Macadamia grower in Hawaii, in making a conservative estimate as to yields, states that in farorable localities the mature Macadamia tree averages 300 pounds of nuts annually, but that in mindy localities, where the trees are not symmetrical in form and the blossoms have become more or less injured, the yields are smaller, possibly varying from 50 to 200 pounds per tree annually. The nut production of the average Macadamia is believed to compare favorably with that of the pecan, the walnut, and the almond. From observations made in Australia it is believed that the Macadamia will produce nuts for a period of 100 years.

\section{NUT CRACKERS}

Recently considerable investigation has been devoted to nut-cracking machines, both in Australia and in Hawaii. R. E. Carney, of California, has invented an electrical nut cracker which has a cracking capacity of 500 to 1,000 pounds of Macadamia nuts per hour. It is also reported $(5, p$. 228) that a St. Louis, Mo., manufacturer has a nut-cracking machine which is adapted to cracking almost any kind of nut. Given a trial with the Macadamia nut, sent to St. Louis from Hoaeae ranch, near Waipahu, Oahu, the machine is said to have worked very satisfactorily. The nuts passed through the cracker, permitting the kernels to fall unbroken from the shells. It is stated that the nuts do not require grading for this machine. It cracks them at the rate of 150 per minute.

\section{SPECIAL INVESTIGATIONS}

Rumsey (16), who recently made an investigation of the Macadamia nut, particularly in Australia, risited a large portion of the country where it grows, both wild in the forest and in cultivation. He observed considerable variation in both the character of the trees and the nuts. He also interviewed the growers, some of whom were growing thin-shelled nuts and were hopeful of developing a marketable strain of that type. A standard variety of thin-shelled nut would prove to be desirable for table use and would offer advantages for cracking when sold on a commercial scale. The Wallongbar Experimental Farm in Australia has also succeeded in developing a comparatively thin-shelled nut by selective breeding, but results of experiments indicate that as yet the variation in the seedling production is too great to maintain a standard variety. Any standard variety of thin-shelled nut must apparently be perpetuated by some 
regetative method of propagation as by cuttings, air layering, or grafting. Mr. Rumsey states that statistics do not show what quantity of Macadamia nuts are produced and sold in Australia. Most of those marketed are collected from the forests or from the groves of farmers. There is a growing demand in that country for all the Macadamia nuts it produces. They sell at prices varying from 6 to 10 pence per pound wholesale and from 1 shilling 6 pence to 2 shillings retail. They are also sold without being graded, but as the supply and demand increase the nuts will likely be sorted according to size by being run through sizing screens. (Fig. 9.) Grading will probably become necessary when cracking machines are generally used in the nut industry, and care must then be taken to avoid breaking the kernel. Broken kernels, however, may be used in the preparation of nut butter and some forms of confectionery.

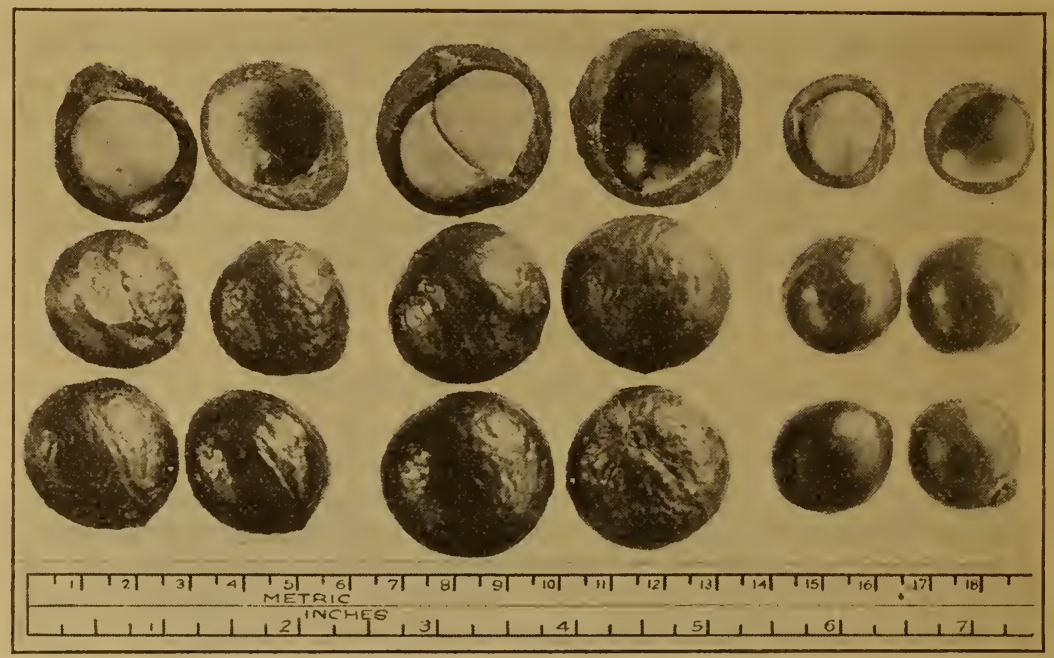

FIGURE 9.- Seedling Macadamia nuts showing variation in size and structure

\section{COMPOSITION AND USES}

In composition the Macadamia nut is similar to most other edible nuts. Table 1 affords comparison of the composition of the edible portion of the Macadamia nut with that of some other nuts and fruits.

TABLE 1.-Comparison of composition of Macadamia nut and some other edible nuts and fruits

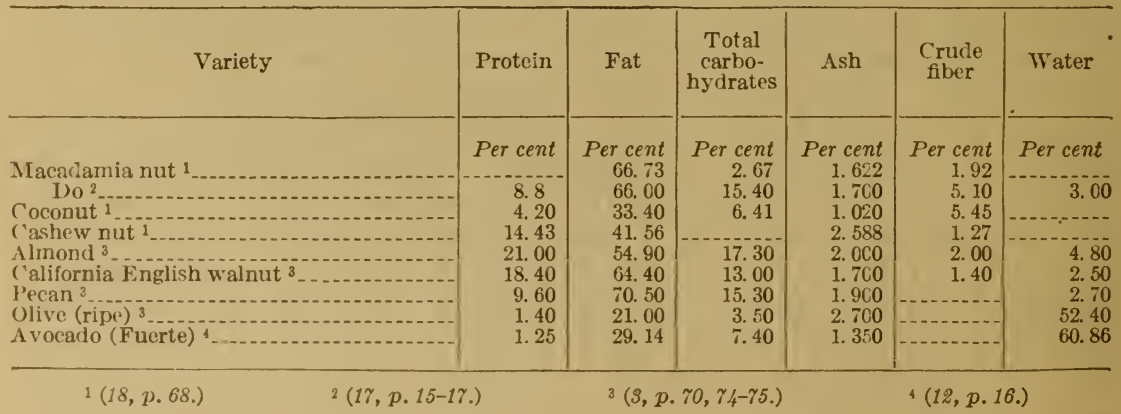


The analyses show that in percentage of fat, the leading substance of the edible portion of practically all nuts, the Macadamia ranks among the highest of the nuts, and it is much higher in this ingredient than are such oily fruits as the ripe olive and the avocado.

Investigations made by Smith and Meston $(1 \%, p .15-1 \%)$ show that the Macadamia kernels are free from starch and from cyanogenetic glucoside, and contain 5.6 per cent of nonreducing sugar. Their tests of the oil extracted from the kernels by cold compression showed it to be limpid, almost colorless and tasteless, and to have a faint odor. When the oil is extracted by a solvent it differ's only in having a light-yellow color. The oil is believed to compare favorably with the finest grade of edible olive oil, and like it apparently could be used for salads $(16, p .21)$, for high-grade soap making, and as a medicine. Macadamia nut meats are also claimed to be superior in flavor and food value to most other edible nuts, including coconuts, almonds, pecans, English walnuts, and cashew nuts. The Macadamia makes an excellent salted nut and also a mild butter which may be used in various ways. The parched kernels have been made into a coffee substitute, much as almonds also are sometimes used. It is also used in cakes, candy, chocolate, and ice cream. The Macadamia is very ornamental and is highly recommeniled for plantings as a shade tree in parks, on privately owned grounds, and along roadsides. When in flower, which it is four or more months in the year, the Macadamia is a good source of honey. 'The wood which is beautifully marked is valuable for cabinetmaking.

VARIATION IN COMPOSITION OF NUTS FROM MACADAMIA SEEDLINGS GROWN AT VARIOUS PLACES IN HAWAII

A series of seven samples of Macadamia nuts was secured from various local growers and from the trees at the station to determine the extent of variation in the composition and flavor of the nuts. Table 2 gives the composition of the nuts:

TABLE 2.-Composition of Macadamia nuts grown at various places in Hawaii

\begin{tabular}{|c|c|c|c|c|c|c|c|c|c|}
\hline $\begin{array}{c}\text { Sample } \\
\text { No. }\end{array}$ & $\begin{array}{l}\text { Nuts } \\
\text { per } \\
\text { pound }\end{array}$ & $\begin{array}{l}\text { Propor- } \\
\text { tion of } \\
\text { kernel }\end{array}$ & $\begin{array}{c}\text { Nuts } \\
\text { required } \\
\text { to pro- } \\
\text { duce a } \\
\text { pound } \\
\text { of kernel }\end{array}$ & Protein & Fat & $\begin{array}{l}\text { Total } \\
\text { carbo- } \\
\text { hydrates }\end{array}$ & Ash & $\begin{array}{l}\text { Crude } \\
\text { fiber }\end{array}$ & Water \\
\hline $\begin{array}{ll}1 & 1 \\
2 & 2 \\
3 & 3 \\
4 & 5 \\
5 & 5 \\
6 & 0 \\
7 & 7\end{array}$ & $\begin{array}{r}\text { Number } \\
69 \\
58 \\
65 \\
53 \\
57 \\
230 \\
38\end{array}$ & $\begin{array}{r}\text { Per cent } \\
34.4 \\
33.2 \\
36.2 \\
29.2 \\
30.8 \\
44.6 \\
24.4\end{array}$ & $\begin{array}{r}\text { Pounds } \\
2.9 \\
3.0 \\
2.8 \\
3.4 \\
3.2 \\
2.2 \\
4.1\end{array}$ & $\begin{array}{r}\text { Per cent } \\
8.51 \\
7.27 \\
8.49 \\
9.79 \\
8.68 \\
7.71 \\
9.19\end{array}$ & $\begin{array}{r}\text { Per cent } \\
76.90 \\
68.70 \\
71.50 \\
67.30 \\
77.30 \\
77.00 \\
76.50\end{array}$ & $\begin{array}{r}\text { Per cent } \\
9.73 \\
15.26 \\
13.30 \\
15.75 \\
9.46 \\
10.20 \\
9.10\end{array}$ & $\begin{array}{r}\text { Per cent } \\
1.64 \\
1.63 \\
1.93 \\
1.89 \\
1.32 \\
1.37 \\
1.50\end{array}$ & $\begin{array}{r}\text { Per cent } \\
1.82 \\
2.42 \\
2.27 \\
2.25 \\
1.92 \\
1.91 \\
2.06\end{array}$ & $\begin{array}{r}\text { Per cent } \\
1.40 \\
4.72 \\
2.51 \\
3.02 \\
1.32 \\
1.81 \\
1.65\end{array}$ \\
\hline
\end{tabular}

1 A round-top type from Oahu. Taken at random from the orchard.

2 From the Kona district, Island of Hawaii. Taken from a single tree bearing large nuts of excellent flavor.

From the Tantalus substation, Oahu. Taken from a single tree having characteristic pink flowers.

- From Hoaeae, Oahu. Taken from a single tree (Hoaeae No. 1), an unusually heavy bearer with large nuts.

${ }_{5}$ From Hoaeae, Oahu. Taken from a single tree (Hoaeae No. 3) having a tendency to produce nuts in large clusters.

From Hoaeae, Oahu. Taken from a single tree bearing small nuts with thin shell and bitter flavor.

7 From Hoaeae, Oahu. Taken from an orchard of trees bearing large-sized nuts. 
Considerable variation is evident in the foregoing table. Selection for large size of nut (samples Nos. 4 and 7 ) did not result in an increase in size of kernel, but in an increase in thickness of shell. Obviously, this method of selection is undesirable.

In chemical composition, the series may be divided into two groups: Samples Nos. 2, 3, and 4, with lower oil content but higher in carbohydrates and water than samples Nos. 1, 5, 6, and 7; and these last-named samples. That this grouping may have some significance is indicated by the fact that a number of persons to whom the samples were submitted pronounced the former group to be the superior in flavor.

Sample No. 6, although a different variety from the others and undesirable as an edible nut, is similar in chemical composition to the other samples.

\section{SUMMARY}

On account of the growing interest in Macadamia-nut culture in Hawaii, an effort has been made to bring together the more pertinent data on the subject and to place on record the results of investigations that have been in progress at the station for a number of years.

The Macadamia nut (Macadamia ternifolia) is a native of Queensland and New South Wales, Australia. It was introduced into Hawaii about 1892, when a few small plantings were made. These trees began to bear in 1908 , and by 1910 considerable interest was aroused in the possibility of growing the nuts in commercial quantities.

A description is given of the tree and the nuts, and suggestions are offered for the propagation of the trees. While the tree is usually grown from seed, methods of vegetative propagation are described whereby strains of superior merit may be extended. Rooted cuttings, air layerings, and grafting were all tested at the station,.and rooted cuttings and side-tongue grafting were found to be the most practicable methods of vegetative propagation.

The Macadamia is strictly a tropical tree and in Hawaii grows from sea level to an altitude of about 2,200 feet. While it is considered to be a drought-resistant tree in Australia, it has done best in Hawaii where there is a rainfall of 30 inches or more or where irrigation is practiced during the drier part of the year. The tree does not appear to be limited to certain types of soil, although in its natural habitat the Macadamia is found in rather rich alluvial soils along creeks and rivers. Strong winds injure the tree, and it requires protection, especially while young. Windbreaks are considered necessary in establishing orchards of Macadamia nuts in Hawaii.

Directions are given for the planting of orchards and for the tillage, pruning, and training of the trees.

Macadamia nuts rank with almonds, pecans, and walnuts in composition, although there was found to be considerable range in the percentage of protein, fat, and total carbohydrates in lots of nuts from individual trees and from different localities.

Macadamia-nut oil is said to compare favorably with the finest grade of edible olive oil and to have some medicinal value. It is thought that the oil could be used to make a high-grade soap and a 
mild butter. It can also be used for salads and in confections, and it is excellent as a salted nut.

\section{LITERATURE CITED}

(1) Axoxymous.

1870. [MACayamia tervirolia.] Gard. Chron. and Agr. Gaz. 1860 (36) : 1181, illus.

(2)

1927. GRowiNg THE MACADAMIA NUT. Coast Banker $39: 695-699,706-707$, illus.

(3) ATwater. W. O., and Woons, C. D.

1906. THE CHEMICAL COMPOSITION OF AMERICAN FOOD MATERIALS. U. S. Dept. Agl., Off. Expt. Stas. Bul. 28, 87 p., illus. (Rev. ed.)

(4) Bailex, G.

1928. M.icadimia cultere. Hawaii Univ. Ext. Letter 321: 267-268.

(5) Forbes. D. M. L.

1928. A HARD NUt Cricked. Hawaii Univ. Ext. Letter 310: 228.

(6) Forbes, D. McH.

192S. information on macadama nut. Hawaii Lniv. Ext. Lettel 316 : $248-249 ; 317: 252-253$.

(7) Higgixs, J. E.

1917. REPORT OF tHe HoRTICULtural Division. Hawaii Agr. Expt. Sta.

Rpt. 1916: 13-21, illus.

1920. report of the horticulteral hivisiox. Hawaii Agr. Expt. Sta. Rpt. 1919 : 16-40, illus.

(9) [P'OPE. W. T. ]

1920. macadana nut. Pacifie Commercial Advertiser 63 (Nov. 16, sec. 2 ) : 2 , illus.

(10) 1922. REPort of the horticultiral Division. Hawaii Agr. Expt. Sta. Rpt. 1921: $8-26$, illus.

(11) 1924. report of the horticultukal division. Hawaii Agr. Expt. Sta. Rpt. 1922: 2-8, illus.

(12) 1924. the guatemalax avocado in Hawail. Hawaii Agr. Expt. Sta. Bul. 51, 24 p., illus.

(13) 1926 . report of the horticlltural division. Hawaii Agr. Expt. Sta. Rpt. 1925 : 3-9, illus.

(14) 1927. REPORT OF THE horticlltural divisiox. Hawail Agr. Expt. Sta. Rpt. 1926: 3-11, illus.

(15) -1928 . The MACADAMIA NUT. Hawaii Univ. Ext. Letter 318: 256-257.

(16) RUMSEY, H. J.

1927. AUSTRALIAN NUTS AND NUT GROWLNG IN AUSTRALA. 120 p., illus. Dundas, N. S. Wales.

(17) Smith, R. F., and Mestox, L. A.

1914. SOME OIL-BEARING SEEDS INDIGENOUS TO QUEENSLAND. I.-THE SEED OF MACADAMIA TERNIFOLIA AND ITS OIL. Roy. Soc. Queensland Proc. 26: [15]-17.

(18) Thompsox, A. R.

1915. THE CoMposition of HaWAIIAN FRUITS AND NUTS. Hawail Agr.

(19) TURNER, F. Expt. Sta. Rpt. 1914: 62-73. IFoldA, F. v. M.). Agr. Gaz. N. S. Wales 4:3-5, illus.

1893. THE CULTIVATION OF THE “AUSTRALIAY XUT" (MICADAMIA TRRN-

(20) WeStgate, J. M

1921. PEPORT OF THE HORTICUltural Divisiox. Hawaii Agr. Expt. sta.

(21) WHITE, C. T. Rit. 1920: $17-26$, illus.

1923. A THIN-SHELLED VARIETY OF THE QUEENSLAND NUT (MACADAMIA TERNifoliA). Queensland Agr. Jour. 20:93-95, illus. 



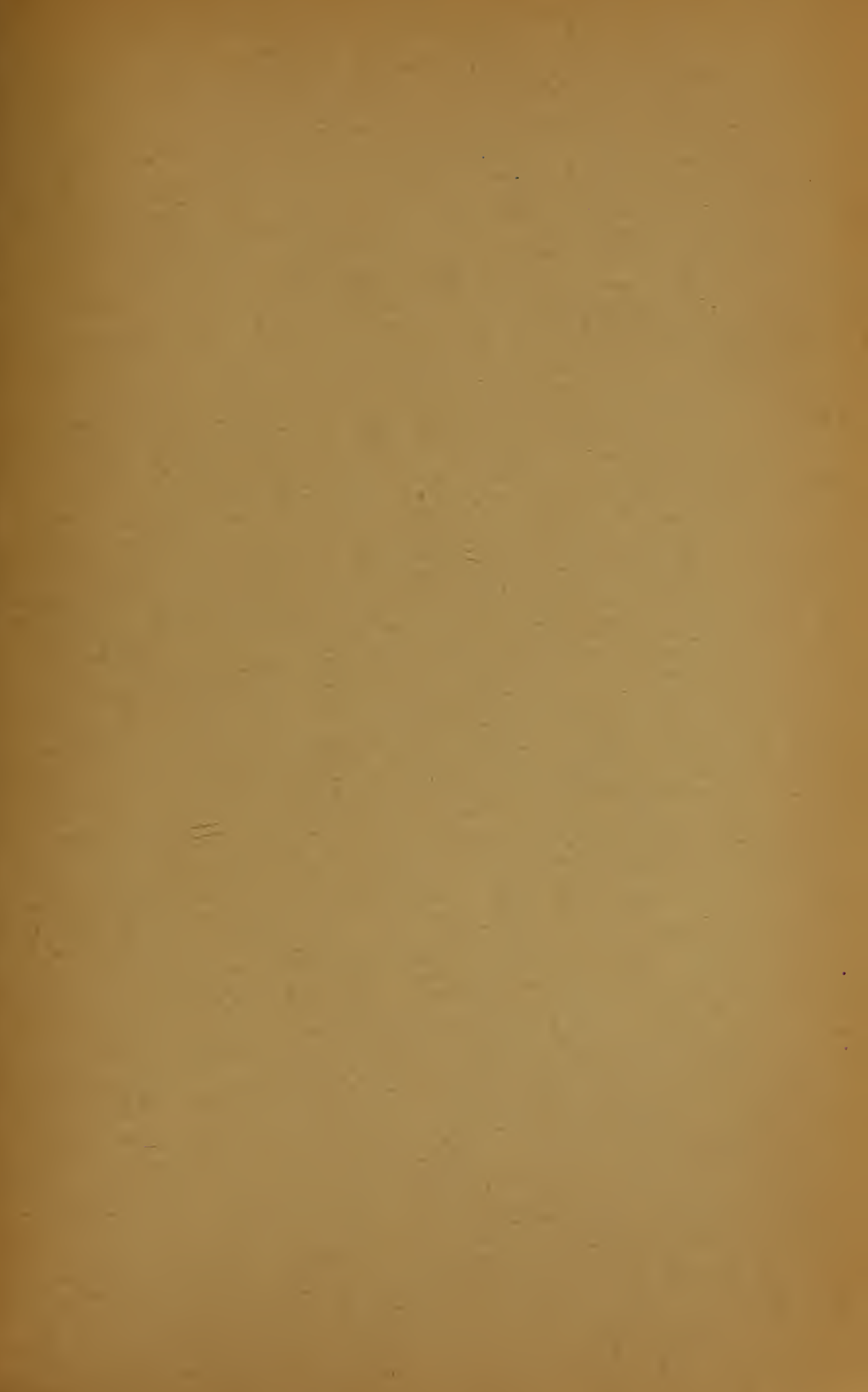


UNIVERSITY OF FLORIDA

31262089290844 